Claremont Colleges

Scholarship@ Claremont

Pomona Faculty Publications and Research

Pomona Faculty Scholarship

$1-1-1986$

\title{
An Unpublished Description of the Villa Doria in Genoa During Charles V's Entry, 1533
}

George Gorse

Pomona College

\section{Recommended Citation}

Gorse, George, "An Unpublished Description of the Villa Doria during Charles V's Entry into Genoa, 1533," The Art Bulletin 68 (1986), pp. 319-322

This Article is brought to you for free and open access by the Pomona Faculty Scholarship at Scholarship @ Claremont. It has been accepted for inclusion in Pomona Faculty Publications and Research by an authorized administrator of Scholarship @ Claremont. For more information, please contact scholarship@cuc.claremont.edu. 
caise Aerts complied by combining two single compositions of Duke Ernst's set of the Trojan War into one, creating the unusual, oversized tapestry of King Priam and His Warriors - Ulysses and Diomed. Narratively, it was the first scene of the set.

The other stories logically followed: Aeneas Fleeing Troy, a double-sized piece; Aeneas and Dido, the only single-sized tapestry; ${ }^{10}$ Coriolanus, double-sized; and Augustus, which originally was also larger than single size. ${ }^{11}$ This format of two long, one short, and two long pieces of tapestry would have made a perfect decoration for a long hall with a short end wall in a European palace. Instead, the tapestries were sent to Japan, intended as diplomatic gifts for high-ranking Japanese nobility, where their di- mensions would fit equally well into Japanese palace architecture. As it turned out, the first piece was presented to Shogun Tokugawa leyasu and hung for three centuries in his family temple of Zōjō-ji, before it was destroyed by fire. The three other doublesized pieces were cut up to fit festival floats; only the single-sized tapestry of Aeneas and Dido has survived intact.

Grace Vlam co-authored Fuzoku-ga; Namban Byōbu, Tokyo, 1979, the fifteenth volume in a corpus of Japanese screen paintings, and has contributed articles to Artibus Asiae, Zeitschrift für Kunstgeschichte, and Kokka, as well as to the Art Bulletin. [1767 Ramona Ave., Salt Lake City, UT 84108]

\title{
An Unpublished Description of the Villa Doria in Genoa During Charles V's Entry, 1533
}

\author{
George L. Gorse
}

\begin{abstract}
Recent scholarship on the Renaissance villa in Italy has emphasized its two major functions, as a pleasure retreat from the city and as a ceremonial entry into the city. This documentary note publishes a previously unknown Mantuan description of the Villa Doria in Genoa. addressed to Isabella d'Este, during the triumphal entry of Charles V into Genoa from March 28 to April 8, 1533. The document has interest for Renaissance scholars as the first description of the Villa Doria and of Perino del Vaga's decorations of 1529-33. It also shows the villa as part of a ceremonial sequence of entry into the city, which helps to explain many aspects of the villa's design and decorative program.
\end{abstract}

The Villa of Andrea Doria in Genoa (Fig. 1), which was built and decorated between 1528 and 1533 , is one of the most representative examples of an Italian Renaissance villa used both as a place for villeggiatura (country retreat from the city) and as a ceremonial entry monument into a city. ${ }^{1}$ Along with the Villa Simonetta of Count Ferrante I Gonzaga in Milan, the Palazzo del Tè of Duke Federico II Gonzaga in Mantua, and the Villa Medici di Castello of Duke Cosimo I in Florence, the Villa Doria became a major court center during the period of Hapsburg consolidation in Italy after the Sack of Rome in May of $1527 .^{2}$

From an unpublished description of the Villa Doria written by the Mantuan ambassador in Genoa to Isabella d'Este, which is transcribed below, one realizes how important a role the villa

This article was made possible by a summer grant from the Pomona College research fund. I would like to thank Professoressa Adele Bellù, Director of the Archivio di Stato di Mantova, for her patient reading of my transcription of the document.

${ }^{1}$ Both functions of Italian Renaissance villas are discussed in D. Coffin, The Villa in the Life of Renaissance Rome, Princeton, 1979. For the Villa Doria as part of a Genoese tradition of villeggiatura and ceremonial entry, see Gorse, 1983, 264-267, and Gorse, 1985, 33- 36.

${ }^{2}$ For this period and its aftermath, see J. Hook, The Sack of Rome, London, 1972. The Villa Simonetta, Palazzo del Tè, and Villa Medici are discussed as court centers in L. Heydenreich and W. Lotz, Architecture in Italy 1400 to 1600, Baltimore, 1974, 228-231, 292-293; K. Forster and R. Tuttle, "The Palazzo del Tè," Journal of the Society of Architectural Historians, xxx, 1971, 267-283; D. Wright, "The Medici Villa at Olmo a Castello: Its History and Iconography," Ph.D. diss., Princeton University, 1976

${ }^{3}$ For these imperial entries and their pictorial themes, see J. Jacquot, ed., Les fêtes de la Renaissance II: Fêtes et cérémonies au temps de CharlesQuint, Paris, Centre National de la Recherche Scientifique, 1960, passim, and B. Mitchell, Italian Civic Pageantry in the High Renaissance, A De- suburbana played during the entrate of Emperor Charles $\mathrm{V}$ into Italy. ${ }^{3}$ The context of this document is Charles V's triumphal entry into Genoa (March 28-April 8, 1533), after his successful defense of Vienna from the Turks, on his way back to Barcelona. ${ }^{4}$ Two other contemporary Genoese accounts of the entry, Paolo Francesco Partenopeo's Annali of 1536 and Jacopo Bonfadio's Annali of $1528-50,{ }^{5}$ emphasize the splendid decorations of the Villa Doria, the emperor's temporary residence in the city, without focusing on the villa as part of a ceremonial sequence, which interested the Mantuan ambassador.

According to the ambassador, the entry evolved in five stages. First, the Doge and Signoria of Genoa, accompanied by two Papal Legates and ambassadors of other states, received the emperor

scriptive Bibliography of Triumphal Entries and Selected Other Festivals for State Occasions, Florence, 1979, 60-63. I am supposing that the Mantuan description printed below was written to Isabella d'Este (1474-1539), although she is not mentioned by name, because it is addressed to the Marchesa di Mantova (Isabella's rightful title), rather than to the Duchessa di Mantova, Maria Palaeologo, whom Duke Federico Gonzaga married in 1531. See J. Cartwright, Isabella d'Este Marchioness of Mantua, 2 vols., London, 1903, and J. Hale, ed., A Concise Encyclopaedia of the Italian Renaissance, New York, 1981, 160-161

${ }^{4} \mathrm{~K}$. Brandi, The Emperor Charles V. The Growth and Destiny of a Man and of a World-Empire, transl. C. Wedgwood, London, 1965, 324-328, and M. Alvarez, Charles V, Elected Emperor and Hereditary Ruler, London, 1975, 97-100. This is the second of five triumphal entries by Emperor Charles V and Prince Philip into Genoa during the first half of the 16th century $(1529,1533,1536,1542,1548)$. See n. 3 above for descriptions of these other Genoese entrate, reprinted in edited form in Gorse, 1980, Appendix $C$.

${ }^{5}$ P. Partenopeo, Annali, (1536), Genoa, 1847, 115- 118, and J. Bonfadio, Annali delle Cose de Genovesi dall Anno mDxxvin sino all Anno MDL. . . , Capolago, 1836, 67-68. 
1 Felice Calvi, Urban View of Genoa, fresco, ca. 1584. Genoa, Palazzo Doria-Spinola (photo: Direzione di Belle Arti, Genoa). Far left, Lantern; left, road into suburb of Fassolo; left center, Villa Doria on waterfront outside city gate of S. Tomasso; right center, Cathedral of S. Lorenzo with campanile

and his entourage at the Lantern on the western point of the harbor basin. ${ }^{6}$ Then the emperor's cavalcade proceeded along the road from the Lantern toward the city, joined by a galley procession and artillery demonstration in the harbor. A young girl dressed as Victory with a palm branch of Peace in her hand welcomed Charles into the city with an oration, presented in front of a temporary triumphal arch at the edge of the suburb of Fassolo on the western outskirts of Genoa where a portable baldacchino supported by gentlemen awaited His Majesty. Caesar and the $\mathrm{Pa}-$ pal Legates then proceeded under this canopy from the triumphal arch to the nearby Villa Doria, where the emperor resided during his visit, conferred with other heads of state and ambassadors, and enjoyed the court entertainments. Finally, Charles entered Genoa along a triumphal way through decorated streets and celebrated Mass at the Cathedral of S. Lorenzo in the città vecchia, paying tribute to its holy relics. In this last stage, Charles' entry

\footnotetext{
- This description should be read in conjunction with city views of Genoa published in E. Poleggi, Iconografia di Genova e della riviere, Genoa, 1977. Cat. Nos. 59-62.

7 See nn. 15 and 17 below for a discussion of this triumphal arch and the villa decorations.
}

was fully consecrated; the emperor symbolically took full possession of the city.

Throughout this description, the Villa Doria appears as the ceremonial focus for the entrata. Perino del Vaga's fresco decorations inside the villa, which are described here for the first time, are shown as complementary to the artist's temporary festival decorations, the triumphal arch at the edge of Fassolo. ${ }^{7}$ Portable decorations, including furniture, tapestries, and other precious cloths, also played a major part in the ambassador's experience of the villa as a unified work of art. ${ }^{8}$ Together the suburb and villa became a ceremonial entryway for the emperor and his entourage.

The Villa Doria's strategic location, overlooking the western entrance into the harbor, undoubtedly contributed to its central position in the entrata. ${ }^{9}$ By virtue of its site between the Lantern and the western city gate of S. Tomasso, the villa physically mediated the relationship between the emperor and Genoa. This and

\footnotetext{
${ }^{8}$ See $n .18$ below regarding crucial inventory evidence that is necessary for reconstruction of these lost components of the villa's decorations.

The choice of location is discussed in Gorse, 1983, 264, and Gorse, 1985. 21.
} 
the impressive scale of the villa expressed the princely status of the patron, Andrea Doria, as a member of the imperial Order of the Golden Fleece with the title of Principe di Melfi, as the first citizen of the Genoese republic, and a servant to the emperor as admiral of the Hapsburg fleet in the Mediterranean. ${ }^{10}$ In the Mantuan ambassador's words, the Villa Doria stood as a casa regia outside the city walls - "not of a gentleman, but of a King" an appropriate base from which the emperor's entrata and symbolic possession of the city could take place.

In transcribing this document I have tried to preserve the archaisms of the sixteenth-century Italian while giving the text punctuation and expanding all the abbreviations for the modern reader. Brackets are used within the text of the document to explain or clarify specific references; these are given in Italian for continuity. The footnotes clarify details and supplement the description with modern bibliographic references.

Archivio de Stato di Mantova. Archivio Gonzaga. Carteggio degli Invitati e Diversi. Genova. Busta 759, No. 310.

Illustrissima et Eccellentissima Signora et Patrona mia osservantissima,

Io me son riservato a scriver a Vostra Eccellentia quando me sia venuta occasione di poterle dar qualche aviso degno de lei, come hor per la entrata de la Caesarea Maestà in questa nobilissima citade. Qual entrata fu giovedi passato circa a le hore xxIJ. El modo che fu servato in honorar detta Maestà, fu questo primo el Duce con li Signori et molti gentilhomini vestiti riccamente di raso domasco et veluto secondo il lor stile, con mule guarnite di veluto, gli andorno un pezzo incontro con el Reverendissimo Cardinale [Gerolamo] Doria. ${ }^{11}$ Dopo essi, li Signori Legati [del Papa] Reverendissimi questi per terra per il mare uscirno del porto galee xxvij molto ben armate, le quali andorno fori desso porto un pezzo di là de la Lanterna costeggiando la riva, et subito che giunsero in loci che potero veder essa Maestà abbasarno le bandiere facendole reverentia alla usanza loro. ${ }^{12}$ Poi scaricorno una gran-

${ }^{10}$ L. Capelloni, Vita del Prencipe Andrea Doria, Venice, 1565, 55ff.; C. Sigonio, Della vita et fatti di Andrea Doria, Genoa, 1598, $75 \mathrm{ff}$.

II Reference to the Doge and Signoria of the Genoese republic meeting Cardinal Gerolamo Doria, a cousin and close adviser to Andrea Doria, who was made Cardinal in 1529 by Pope Clement VII.

${ }^{12}$ It was normal practice to welcome monarchs and important people into the city by receiving them near the Lantern and entering through the west gate of S. Tomasso. See Jean D'Auton, Chroniques, Paris, 1835, in, $58 \mathrm{ff}$. for a contemporary description of the French king Louis XII's entry into Genoa in 1502. Discussed in Gorse, 1983, 258. L. Grossi Bianchi and E. Poleggi, Una città portuale del medioevo, Genova nei secoli $x-x v I$, Genoa, 1980, fig. 156, publish a manuscript illumination of this entry, showing the Lantern and Porta S. Tomasso.

${ }^{13}$ Artillery barrages play an important part in the reception of the emperor into the port, as described in his first entry of August, 1529. See G. Romano, ed., Cronaca del soggiomo di Carlo V in Italia (dal 26 luglio al 25 aprile 1530), Milan, 1892, 78-81.

${ }^{14}$ This part indicates that Genoese galleys followed the emperor's cavalcade near the waterfront from the Lantern toward the city, adding a naval barrage to the land procession.

${ }^{15}$ This passage suggests that a temporary triumphal arch was placed at the edge of the suburb of Fassolo to indicate that the emperor was residing at the Villa Doria and not within the city. Significantly enough, it is at the triumphal arch where the emperor symbolically enters the city (the borgo, not the city gate) and is met by his ceremonial baldacchino that figures prominently in all the festival descriptions (see n. 3 above). Two drawings for triumphal arches by Perino del Vaga, who worked for An- dissima quantità de artigliaria, e voltorno pur costeggiando la riva ut supra, andando ritenuti per esserle sempre a pare..$^{13}$ Come detta Maestà giunse alla punta del porto ove è la Lanterna, una nave che era scostata da l'altre che erano nel porto studiosamente, visto che hebbe un segno che le fu fatto da un battello con un panno bianco, incomincio a sparar artigliarie, et dopo essa tutte le altri navi che erano in gran numero. El strepito era horribile, et tanto el fumo che per un pezzo non si vedrano le navi. Poi che le galee furno nel porto pur andando sempre più appresso alla riva che poteano a pari de la cavalenta, fecero la medesima reverentia alla Maestà Caesarea, e sparorno un'altro tiro de artigliaria. ${ }^{14}$ Questa fu cosa bellissima a vedere. Et perchè prefata Maestà non è alloggiata dentro da la terra [dentro la città] come la intendera, fu fatto un arco triumphale in capo el borgo [in sobborgo di Fassolo] ove una frotta de gentilhomini l'aspettavano con el baldacchino di brochato. ${ }^{15} \mathrm{Al}$ detto arco era una fanciulla di qualche anni xiJ, vestita da una victoria con la palma in mano, la quale recito una oratione con bon animo et assai bona gratia. ${ }^{16}$ Sotto el baldacchino era la Caesarea Maestà et li dui Reverendissimi Legati, dopoi el Reverendissimo Doria, Duce et Signoria, et li altri gentilhomeni. Cosi fu accompagnata nel palazzo del Signore Principe Andrea Doria, el qual palazzo é immediate fuor de la porta [di San Tomasso]. El sito di questo palazzo me voglio riservar a dir a bocha a Vostra Eccellentia. Solo le diro che vi erano dui salotti uno a mano dextra [Sala dei Giganti] in capo de una loggia bellissima [Loggia degl'Eroi] nela quale se entra in capo de la scala, l'altro salotto de la medesima grandezza alla sinistra [Sala di Nettuno], et questi sono accompagnato da quattro alloggiamenti tra camere et camerini bellissimi in volta tutti dipinti nel volto de stucchi e grotteschi bellissimi, come sono tutti le alloggiamenti di sopra. ${ }^{17}$ Questi salotti, che son de bellissima quadratura et con camini di marmore superbissimi, insieme con le stantie erano tutti apparati di cortine alte, parte di veluto et tela d'argenti, parte di veluto et domasco, parte de panno de oro richissimo con le lettiere de li medesimi drappi et colori reccamati

drea Doria on the decorations of his villa between 1528 and 1536 , have been published for these festivals. However, there is no agreement on when these drawings were executed (for the 1529,1533 , or 1536 festivals?) or for what site (within or without the city?). See discussion in S. Jacob, Italienische Zeichnungen der Kunstbibliothek Berlin, Berlin, 1975, No. 53; W. Eisler, "Perino del Vaga - Triumphal Arches for the Entrance of Charles V into Genoa, 1529," Il polittico di Sant'Erasmo di Perin del Vaga, Mostra: Museo dell'Accademia Ligustica, Genova, 1982; Gorse, 1985, $33-$ 35. I would add that Perino's triumphal arch(es?) were probably constructed of wood and painted, which means that they could be taken down and reassembled. This reuse of festival decorations also contributes to the consistency of entry traditions, which many of the descriptions of these events dwell on.

16 The oration all antica, given by a young girl dressed as a Victory figure with palm branch in hand (as a reference to peace), was another frequent convention of the entrata. See Romano (as in n. 13), 82: ". . . una bellissima et elegante oratione, offerendoli la Città, li figliuoli, le facultade et loro proprij all servicij di sua Maestà Cesarea."

17 These sentences focus on Perino del Vaga's decorations on the second floor of the Villa Doria, including the central Loggia degl'Eroi, the flanking Sala dei Giganti and Neptune rooms to west and east, and four smaller camere in each of the two adjoining apartments. For the decorations, see B. Davidson, "Drawings by Perino del Vaga for the Palazzo Doria, Genoa," Art Bulletin, xuI, 1959, 315-326, and E. Parma-Armani, "Il Palazzo del Principe Andrea Doria a Fassolo in Genova," L'arte, x, 1970, 12- 59. Relationships between the decorations and architectural plan are discussed in Gorse, 1985, 23-27. 
di argento et oro. ${ }^{18}$ In la camera del Imperatore, apparata di panno d'oro et veluto violato, erano due lettiere, ma una ricchissima, con una coperta di reccamo bellissimo. ${ }^{19}$ Tutte haveano cossini reccamati et lenzoli di gran ricchezza. Sotto li cortinaggi di veluto oro et damasco, come dicto ho di sopra, erano panni de razzi bellissimi, che haverano bastato a ornare ogni casa regia, di figure molto ben fatte. Et perchè la Caesarea Maestà non havesse causa di spiegare cosa altura per el bisogno suo, era nel salotto da man dextra [nella stanza di Carità] apparecchiato un bellissimo palio da altare con li altri fornimenti da cappella, et el baldacchino ove havesse a star sotto detta Maestà ricco secondo che costuma quando o di la messa. ${ }^{20} \mathrm{Me}$ fu ancor detto per persona che lo havea visto, che havea fatto far dui bellissimi bacili d'argento per dar l'acqua, et altri argenti per servitio de la tavola. Questo apparato ha fatto tutto del suo el detto Principe [Doria], e con tanta celerità che è cosa incredibile. Dicto apparato non è da un gentilhomo, ma da un gran Re. Ha fatto far una galea nova maggior de l'altre a posta, perchè habbia a portar la Caesarea Maestà heri fu posta a l'aqua. ${ }^{21}$ Intendo che ha fatto far l'apparato bellissimo per la camera ove ha era a stare in detta galea, et vole far lavar tutta la ciurma [principalmente condannati e schiavi], e radire in ogni loco, poi la veste de veluto de dui colori. E fa una coperta di scarlato alla galea di sopra in cambio di celega, vele bandieri et simil cose bellissime, de le quali non posso dar a Vostra Eccellentia particular aviso, perchè ancor non son stati viste. La gente che era in qual borgo a molte passar la Maestà Caesarea era molta, ma sopratutto numero grandissimo di donne, et molte belle et ben vestite secondo l'usanza de la terra. Heri prefata Maestà ando a Messa nel Domo [di San Lorenzo in centro città] ove era un popolo innumerabile, et altrettanto per la strada ove passava la quale non era manco de un miglio de la casa del Principe [Doria] insino alla chiesa. ${ }^{22}$ Per questa strada, et ne la piazza del Domo et esso Domo, era tanto numero di donne maritate et da marito, che era un stupore et belle ut supra.

Io non ho possuto dar aviso particolar de li apparati de la casa del Principe [Doria], perchè seria stato bisogno ch'io havessi ha- vuto da scriver con mito, s'io gli potro tornare che non vi sia la Caesarea Maestà, faro opera di saper dir tutto. Resta a veder inbarchar detta Maestà che si crede sera cosa bellissima la qual dice voler partir hoggi ad otto, servendola el tempo. Ancor che l'armata de le navi grossi non possa esser a qual di in ordine, ma non è necessaria, perchè seranno in numero di trenta galee armate di modo che passariano per mezza ad ogni armata secure.

Monsignor Illustrissimo sta bene: ogni di andanno in brevibus a veder giardini, che son tanto belli che me par ch'el esser nasciuto a Genova oblighi molto li habitanti alla natura. A Vostra Eccellentia bascio humilmente le mani. De Genova ultimo Marzo 1533.

De Vostra Illustrissima et Eccellentissima Signora.

Humil Servitor, Ludovico da Bagno

Address on Outside of Document:

Alla Illustrissima et Eccellentissima mia Signora et Patrona osservantissima la Signora Marchesa de Mantova

George L. Gorse, who is Viola Horton Associate Professor of Renaissance Art at Pomona and Scripps Colleges, has published articles on Genoese Renaissance villas in The Journal of Garden History and The Journal of the Society of Architectural Historians. [Art Department, Pomona College, Claremont, CA 91711]

\section{Bibliography}

Gorse, G., 1980, "The Villa Doria in Fassolo, Genoa," Ph.D. diss., Brown University.

, 1983, "Genoese Renaissance Villas: A Typological Introduction," Joumal of Garden History, III, 255-280.

. 1985, "The Villa of Andrea Doria in Genoa: Architecture, Gardens, and Suburban Setting," Journal of the Society of Architectural Historians, XLIV, 18-36.
18 The following sentences highlight the portable decorations, which unfortunately no longer exist, with the exception of a few extant tapestries. See E. Pandiani, "Arredi ed argenti di Andrea Doria da un inventario del 1561," Atti della Società Ligure di Storia Patria, LII, 1926, 241-297, and A. Erkelens, "Rafaelëske grotesken op enige Brusselse wandtapijtseries," Bulletin van het Rijksmuseum, Iv, 1962, 115-138 (and discussion of inventory evidence in Gorse, 1980, 81- 87)

19 The emperor's residence was in the west apartment, normally occupied by Andrea Doria, near the Sala dei Giganti, which was transformed during these imperial visits into a throne room. See Gorse, 1985, 34-35, for the later entry of 1548 .

20 The Carità room, with a painted female figure of Caritas Romana feed- ing a prisoner on the ceiling, established an appropriate moral theme for the palace chapel. See the discussion in Gorse, 1980, 60-61, and Gorse, 1985, for the location of room (W3 on the plan reproduced in fig. 10).

21 This galley is mentioned in a number of Doria's letters to Charles V during this time, and it is likely that Perino del Vaga had a hand in the galley decorations. Vasari-Milanesi, v, 617, mentions ". . . similmente i begli ornamenti disegnati da lui [Perino] nelle poppe delle galee, intagliati e condotti a perfezione dal Carota e dal Tasso, intagliatori di legname fiorentini, i quali eccellentemente mostrarono quanto évalessino in quell'arte."

22 The procession to the Cathedral as a major entry event is also described in Prince Philip's entrata of 1548. See Gorse, 1980, 404-405. 
Copyright of Art Bulletin is the property of College Art Association and its content may not be copied or emailed to multiple sites or posted to a listserv without the copyright holder's express written permission. However, users may print, download, or email articles for individual use. 